\title{
Nietzsche and our discourses on identity
}

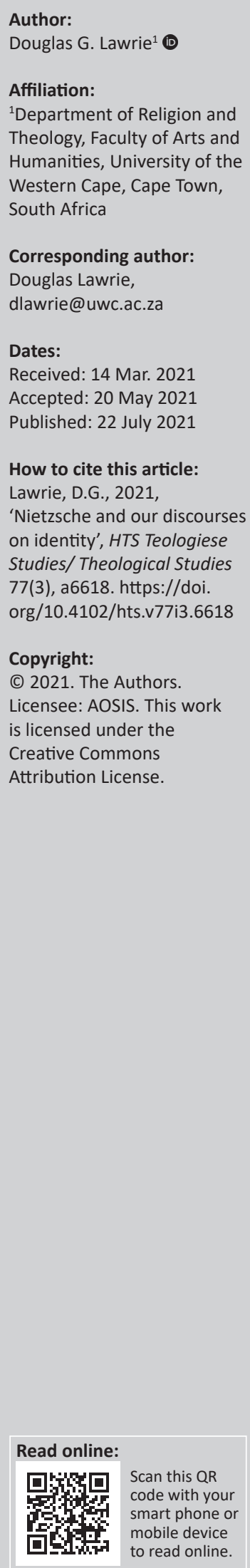

Through his views on perspectivism and the will to power, Nietzsche indirectly influences many current discourses on identity. This article places these themes in the broader context of Nietzsche's thought. Firstly, it is indicated how difficult it is to speak of someone's identity by showing how many 'Nietzsches' appear in his writings, notebooks and letters and the accounts of his contemporaries. Such comparative readings, although they may cast new light on Nietzsche's philosophy, are rare in Nietzsche scholarship. Next, his views on identity are briefly explored, paying attention to his rejection of the centred subject, equality and morality and his view on hierarchy, creativity and power struggles. Finally, it is argued that Nietzsche confronts our discourses on identity with challenges regarding the ubiquity of power struggles, the role of ressentiment, the possibility of communication across boundaries, the importance of the individual and the problem of affirmation.

Contribution: Discourses on identity, although fashionable, are often confusing. Instead of offering solutions, this article uses Nietzsche's life and philosophy to identify some causes of confusion and indicates where crucial decisions regarding our presuppositions have to be taken. Its aim was not to produce knowledge but, in line with Nietzsche's practice, to 'produce ignorance', to question the terms we use confidently, without fully considering their meaning or implications.

Keywords: Nietzsche; identity; will to power; hierarchy; perspectivism; ressentiment; personhood; types; affirmation.

\section{Introduction}

Although Nietzsche wrote to Lou Salomé 'werde der, der du bist' (BVN-1882, 239; cf. FW-82, FW-102) and subtitled Ecce Homo 'Wie man wird, was man ist', he seems an unlikely contributor to debates about identity. To him the notion of identity (Identität) depends on the false assumption 'dass es gleiche Dinge gibt' (NF-1885, 36 [23]; cf. FW-56). It is mistaken to believe that people have shared 'identities' that allow us to treat them alike (NF-1880, 6 [144]). Nevertheless, Nietzsche, through the interpretations of Heidegger, Deleuze and particularly Foucault, exerts a hidden influence on current identity discourses. This becomes evident in two common subtexts in these discourses.

The first is that identity is a function of power relations. Identity predisposes people to think and act in specific ways, but within the ubiquitous network of power relations identity is constantly under threat, setting up an interplay of domination and resistance. In this struggle the sole constant is the will to power. The second is that identity emerges from the perspective of individuals or groups. As perspectives reflect different life experiences, they cannot be assessed or compared from a neutral, privileged position. Significantly, Stanley Fish (2016) cites Nietzsche's perspectivism to support his view that groups with different 'vocabularies' and 'basic assumptions' see different 'truths'. At least he envisages conversations between groups that could lead to agreement.

Through his perspectivism and view on power, Nietzsche appears in the 'genealogy' of our discourses, yet these are strands in a complex web, and Nietzsche said, philosophers should not 'isolate thoughts' (GM-Vorrede-2). In the conclusion it is argued that challenges to our identity discourses emerge when these are linked to other aspects of Nietzsche's thought: his elitism and his rejection of human rights, compassion and what we call morality. Before that, however, come some 'showing' and 'telling' (cf. Millgram 2012:10f). After showing how difficult it is to assess an identity by considering Nietzsche from various angles, his views that bear on the matter, as expressed in his writings, are briefly summarised.

Note: Special Collection: New Landscapes in Identity: Theological, Ethical and Other Perspectives, sub-edited by John Klaasen (University of the Western Cape). 


\section{What Nietzsche showed about identity}

Nietzsche explicitly rejected the 'centred subject' (NF-1885, 40 [42]; JGB-17 and often). Indeed, his writings, notes and letters and the accounts of contemporaries suggest that there were many Nietzsches.

In part, he simply developed. His early writings drew on Wagner's romanticism and Schopenhauer's pessimistic metaphysics. From Menschliches, Allzu Menschliches I (1878) onwards, he was a Freigeist leaning towards positivistic science. From Die fröhliche Wissenschaft (1882) onwards, he developed his own thoughts. Lou Andreas-Salomé (1894:49-207), who proposed this division, gives many examples to illustrate the transitions.

The lines, however, are blurred. When he wrote Wagner in Bayreuth (1876), he was already critical of Wagner (Cate 2003:209f). Andreas-Salomé (1894:140) places the next division after Die fröhliche Wissenschaft but admits that Morgenröthe and Die fröliche Wissenschaft straddle two periods. Towards the end, Nietzsche's sanity became questionable: Ecce Homo (manuscript 1888, published 1908) is hardly the work of a fully sane person. But are Der Antichrist (1888) and Götzen-Dämmerung (1888), given their vehemence (see GD-Streifzuege-38) and gratuitous attacks on, for instance, George Sand, (GD-Streifzuege-6)? This after saying at the end of the previous section that, being ja-sagend by nature, he engaged in criticism unwillingly (GD-Deutsche-6).

Nietzsche's notebooks and letters, instead of clarifying matters, confuse the picture further. Sometimes he was less guarded in them, sometimes more tentative and self-critical. He identified traces of fanaticism in his early writings (NF-1880, 3 [1]) and regarded their style as too diffuse (NF-1880, 8 [33]). He admitted that in his 'untimely meditations' he was among the most modern of modernists (NF-1885, 2 [201]). The statement that it is unworthy of a philosopher to hate mediocrity (NF-1887, 10 [175]) was probably meant for himself - although he ignored it. A note, clearly intended for the preface of a book, suggesting that he had taken a public position too early and now had to retract, never appeared in print (NF-1876, 23 [159]). Similarly, his praise for the Parsifal overture - at a late stage - was not repeated in print (BVN-1887, 793, to Köselitz). Apparently he was unwilling to be too self-critical in print.

Some notes reflect earlier stages in Nietzsche's thought. Although never a socialist, his early notes on socialism are mild. Socialists do not overlook differences among people but argue, partly rightly, that these are negligible (NF-1876, 23 [25]). He grants socialists that mindless labour causes great suffering to educated workers, the hint of compassion beings in line with Nietzsche's early view of compassion as a minor virtue (cf. NF-1876, 19 [9]). But his 'solution' is jarring; 'barbarische Völkerschaften' from Asia and Africa can be imported to do the hard work (NF-1877, 25 [1]). Later he said that he hated the 'Socialisten-Gesindel' above all (AC-57; cf. NF-1887, 37 [11]; Van Tongeren (2015) traces a similar development in his handling of democracy). The English, first hailed as the torchbearers of Europe (NF-1876, 23 [170]; cf. VM-184), later became the cause of all Europe's ills (JGB-224).

Four late notes deal with Schopenhauer's suggestion that some should be castrated to prevent them from reproducing. Firstly, Nietzsche says that criminals should be treated as morally guiltless rebels against the social order unless they belong to the 'Rasse des Verbrecherthums'. Then they should be castrated forthwith (NF-1887, 10 [50]). In the next two (NF-1887, 10 [100]; NF-1887, 10 [104]) he rejects the suggestion (for criminals and other groups). Criminals are at least not mediocre! Finally, he says that incarceration and castration can be considered to prevent some from reproducing (NF-1888, 23 [1]). Such notes clearly reflect a flux in Nietzsche's ideas; what he would have published remains unknown.

The letters contribute as well. Although Meta von Salis (ed. Gilman 1987:210) said that he seldom complained about his suffering, his letters to those closest to him teem with complaints. While he wrote that 'higher people' like him prefer and need solitude, he frequently bewailed his solitude and lack of friends. Yet he did avoid most company, for he abhorred anything zudringlich. In his letters he was not as polite as he was in person. Paul Lanzky, who was of great use to him and was initially hailed as a disciple (BVN-1883, 477, to Overbeck), soon bored him and became unausstehlich (BVN-1885, 568, to his mother and sister) and finally an author 'of the tenth rank' and 'inwardly corrupted' (BVN-1887, 884, to von Meysenbug). Von Salis considered him supportive of women who excelled (ed. Gilman 1987:200). To his sister he wrote (BVN-1887, 925) that he could barely tolerate her and her friend - 'dieser ... im Grunde unerquicklichen, wenn auch sehr achtbaren Weiblichkeiten'. His remarks to Overbeck about his mother and sister (BVN-1883, 386) typify a tendency to criticise some people in letters.

Zarathustra's advice to his disciples to 'Be hard' (Za-IIITafeln-29) was possibly meant for himself, as Marie von Bradke guessed (ed. Gilman 1987:12). Ida Overbeck called him 'hypersensitive' (ed. Gilman 1987:121), von Salis 'easily offended' (ed. Gilman 1987:202) and von Schirnhofer '[suffering from] emotional hyperaesthesia' (ed. Gilman 1987:194). When offended, he reacted vehemently. His letters to Lou Salomé and Paul Rée (and others) after their parting were often vindictive and childish (for instance BVN-1882, $351,352,353,354,360,362$; some, extant only in draft, were perhaps not sent). What he called Salomé in a letter to Rée's brother (BVN-1883, 435) is best not repeated. Writing to his sister (BVN-1887, 968, draft only), he recalled all those who had hurt him, including Ida Overbeck and Malwida von Meysenbug. An increased petulance and sense of selfimportance showed in some letters before other signs of 
insanity appeared. Von Bülow, who had not answered a letter of his, was told that he must be aware that the foremost mind of the age had requested something of him (BVN-1888, 1129). About Zarathustra he was always wildly unrealistic (for instance, BVN-1884, 511; BVN-1888, 1064). Even his old friends Erwin Rohde (BVN-1887, 846, 849) and Malwida von Meysenbug (BVN-1888, 1131, 1135) were not spared.

Those who 'paper over' contradictions in Nietzsche's writings, as Millgram (2012:14) complains, may learn from the letters that he contradicted himself frequently about mundane matters. As he admitted himself (FW-295), he fluctuated on what people and places he liked, whether his health was improving or deteriorating and particularly what diet suited him - to the amusement of some friends (ed. Gilman 1987:144, 179f). The one constant was the air of oracular certainty, the 'peremptory insistence' against which Rohde warned him (Cate 2003:193), with which he expressed each new view. Casual readers may overlook his moodiness, which he himself recognised (MA-I-32).

Acquaintances seldom saw him as the firebrand of the writings and (sometimes) the letters. Lanzky, having found some of his letters 'harsh and arrogant beyond measure' (ed. Gilman 1987:173), was surprised by his 'humaneness' and 'amiability' in person (ed. Gilman 1987:179). AndreasSalomé (1894:19) speaks of his 'fast weiblichen Milde'. He is often described as polite, friendly, witty and, mirabile dictu, modest (see ed. Gilman 1987:91, 171, 172 - different people). Most were favourably impressed, although the intelligent ones showed more indulgence than reverence. Some external testimonies may be relevant to his philosophical work. At school he was 'extremely weak' at mathematics (Deussen in ed. Gilman 1987:18, confirmed by others). Is this why he apparently found it hard to write systematically? About his use of opiates, particularly chloral hydrate, we learn mostly from outside sources (see ed. Gilman 1987:100, 164, 179f, 216, 230, 244 - all different people). Yet even when he was practically an addict, he kept fulminating against 'narcotica' and 'alcoholica' (e.g. FW-147, GM-III-21, GD-Deutsche-2, NF1888, 15 [32]). Did addiction contribute to his erratic behaviour in later years?

There are some constants. Nietzsche consistently praised courage and cleanliness (mental and physical), regarded friendship highly and opposed the death penalty. The idea of 'self-overcoming' appeared early on (Cate 2003:31f), so did the irrational notion that the truth is ugly and unpleasant, hinted at in an early letter to his sister (BVN-1865, 469) and later stated bluntly (NF-1887, 11 [108]; NF-1888,16 [30]; cf. Bittner 2003:xxviii). His elitism, sometimes amounting to snobbery, was always there, coupled with disdain for 'the rabble'. Überflüssigen (Za-I-Goetzen) is an example of his many pejoratives for the latter. He desperately wanted to be vornehm and later called himself a Polish nobleman of pure blood (EH-Weise-3). But do such disparate traits amount to an 'identity'?
Although exceptional, Nietzsche bore the imprint of his time and was not as creative as he gave himself out to be. Schmidt (2016) showed how often he took credit for the ideas of others. On the importance of the unconscious (e.g. FW-333), he relied particularly on Erich von Hartmann, but the idea was fashionable (Schmidt 2016:92f). So was the apparently novel idea that matter can be reduced to energy (Kraft) (Schmidt 2016:17ff.). On eugenics he was influenced by Galton (Cate 2003:448). Trusting Nietzsche's own account, scholars downplay his reliance on Rée's ideas in his Moralkritik, but Schmidt (2016:40ff) gives evidence of substantial borrowing. His borrowings from Hume (on morality, causality and the subject), Kant (the transcendental method; cf. Bittner 2003:xxvi) and Hegel (on logic) also went largely unacknowledged. Schmidt (v) exaggerates when he calls Nietzsche 'Kompilator und Plagiator', for we all borrow from others. But Nietzsche's lectures on rhetoric that so impressed De Man (1979:104ff) really were compiled from sources (see Porter n.d.).

To separate Nietzsche's philosophy from his life and 'identity', as many scholars do, is to ignore what he consistently said himself (JGB-6; NF-1886, 6 [4] and often). But can we know someone who had 'eine Freude an der Verkleidung' (Andreas-Salomé 1894:19) and asked his shadow for another mask (JGB-278)? One, also, who said that he did not want to be understood by everyone (FW-381), that his books were poison to those who had 'no right to them' (FW-359; JGB-30)? Was what made 'Nietzsche' inherited, socially constructed by the Zeitgeist or foisted on him by contemporaries - and current scholars? Did his masks reflect changing moods or unconscious motivations, or did he intentionally use them to create identities? What role did his poor health and drug abuse play? How did the flux that he saw in all things affect his identity? [On the role of Vererbung in Nietzsche, see Schacht (2013:334ff.) and Leiter (2019:166ff). 'Alles Gute ist Erbschaft' (GD-Streifzuege-47; cf. FW-54; JGB 228; GM-I-3 and often)].

For one who claimed to write only of 'erlebter Dingen' (NF-1884, 27 [77]; cf. NF-1886, 6 [4]), staked much on his identity $(A r t)$ and refused to be verwechselt with anyone (EHVorrede-1), Nietzsche presents a flickering image - as if he were one of the Mischmasch-Menschen (GD-Verbesserer-3) he despised. If we say that 'higher people' are too complex to have identities, while herd animals have identities because they are boringly similar and without Geist, we grant Nietzsche his elitism. But then do we know our own identities? 'Bist du echt oder nur ein Schauspieler, ein Vertreter oder das Vertretene selbst? - Zuletßt bist du gar bloß ein nachmachter Schauspieler ...' (GD-Sprueche-38).

Given this, it may be better to use the word 'identity' sparingly - as shorthand for a complex set of problems. Even then it is 'verbal' rather than 'nominal': it is enacted, performed, attributed, adopted and waved as a banner. And although few people are as clever, witty and skilful with words as Nietzsche was, he admitted that all people are infinitely complex (JGB-225). 


\section{What Nietzsche told about identity}

Nietzsche was interested in exceptional people, not in large groupings. 'Humanity' to him was an experiment on the way to 'higher types', the highest being the overman (Übermensch), the meaning and purpose of life and the earth (Za-I-Vorrede-7; Za-I- Vorrede-3; NF-1884, 26 [232]), who would relate to us as we do to apes (Za-I-Vorrede-3) and would replace God (Za-IV-Menschen-2). Overmen have not yet appeared (Za-II-Priester), but we may prepare the way for them (Za-II-Tugend-2; Za-II-Inseln).

But the overman is not an evolutionary stage in human development (EH-Buecher-1) and will not abolish inequality (NF-1883, 12 [43]; NF-1884, 27 [23]). Most people are and will remain 'excess production' (NF-1888, 14 [8]; cf. JGB-126; GM-I-16). Group identity, he might have said, is for these, who necessarily seek strength in numbers. There is something in this. When I speak 'as a worker (woman, etc.)' or 'on behalf of workers', my puny voice is amplified. If contradicted, I 'prove my point' by saying that my interlocutors are capitalists or did not share 'our' pain (which was largely not mine). Moreover, as I derive my voice and agency from the group, I will generally conform to the group and avoid thinking for myself. Although shared experience sometimes plays an independent role in forming group identity, the shared experience itself is often created by conformism and is not unmediated. Such speculations are in Nietzsche's spirit, not in his words.

Nietzsche had an ambiguous attitude towards this dynamic. While despising conformists, he valued the stability the 'broad base' brought to any society (NF-1887, 174]; NF-1888, 14 [82]; AC-57). Being predictable, the mediocre are boring, yet also reliable. 'Higher people' like him, being 'explosives' (GD-Streifzuege-44; EH-Schicksal-3; cf. EH-Schicksal-1), do not keep the wheels of industry and agriculture turning. The stability, however, comes at a price. The producers reproduce from generation to generation the same customs, habits, thought patterns and standards of judgement, thus creating, for instance, 'national identities'.

On national identities, which fascinated him, Nietzsche was guilty of 'reckless generalisation' (Bittner 2003:xiv; see JGB-240-259 and elsewhere). Arguably the generalisations contain a grain of truth, but Solomon (1994:120f) rightly criticises of the implicit 'biological determinism' behind this. Nietzsche had argued that one can postulate identity as sameness only by lying, but added that we need precisely such lies to live (MA-I-Vorrede-1; FW-121; NF-1886 [379]; NF-1887, 9 [89]). Perhaps he needed deceptive generalisations about, for example, Germans to live with himself. Perhaps academic discourse on identity is also based on useful lies useful to the academics.

Some call Nietzsche an individualist or egoist; others deny that he could have been either, as he regarded the individual and ego ('subject', 'I' etc.) as mere verbal constructs. Like Hume, he denied that ' $\mathrm{I}$ ' refers to any discernible entity.
Human beings are neither psychically nor physiologically unities (NF-1887, 9 [91]); they harbour many distinct drives and personalities (JGB-1; JGB-12) and resemble states or societies comprising many 'individuals' (NF-1881, 11 [130]). Nor are they a stable mix of components inhabiting a stable environment: they and their world are in constant flux (WS-11; NF-1887, 11 [98] and often). Even personal identity is questionable because no person is ever self-identical - 'die Gleichheit mit sichselbst' (NF-1887, 9 [91]) is a fiction. What remains unchanged is the quantum of power in the system as a whole (NF-1885, 2 [143]).

[Nietzsche's speculations, mainly in the late notebooks and frankly metaphysical (pace Clark 1990:98ff), raise problems that cannot be discussed here. Bittner (2003:xv-xxviii) offers a good orientation. If most things (will, causality, matter itself) are mere verbal constructs (FW-354; GM-I-13; GD-Vernunft-5), the night in which all cows are black, the bane of vitalist philosophies, looms. How does one imagine a transcendental reality that is 'a different type of phenomenal world', not the 'real world' (NF-1887, 9 [106]) or a struggle for power even at the level of cells (NF-1885, 40 [55]) and atoms (NF-1185, 43 [2])? But Nietzsche did see problems that others blithely overlook.)

Nietzsche held that life requires both flux and stability. In human beings stability is provided by relatively stable types, each marked by a quantum of power (NF-1887, 10 [118]; NF-1887, 11 [36]). Leiter (2020:1.2) says, 'Each person has a fixed psycho-physical constitution, which defines him [sic] as a particular type of person' and explains the person's actions. Since power is the criterion, types are arranged in a strict hierarchical order (Rangordnung) from higher to lower. The characteristics of a type remain relatively stable across generations. For instance, the sons (!) of the elite perpetuate the type because they get the best wives and education (MA-I-479; cf. NF-1885, 35 [76] on Geblutsadel; NF-1888, 14 [133]). Nietzsche supported for a programme of eugenics to preserve and strengthen 'higher people' and shifted his attention from Bildung (education) to Züchtung (breeding, training, discipline). Ideally, the distinction between the various types should be clear and should, if anything, increase (NF-1888, 15 [62]) to strengthen the 'pathos of distance'

People of the same type share enough characteristics to allow us to ascribe a group identity to them. Although not the same or equal, they are roughly equivalent, making Gleichstellung among them possible (MA-I-93). Nietzsche's speculation about the origins of justice illustrates this. When 'higher people' had a dispute, they sought an equitable settlement instead of expending their power in a roughly equal battle. The model for the settlement was the notion of 'equivalent value' in commercial transactions (MA-I-93; M-112; JGB-265; GM-II-4). But this holds only inter pares (NF1885, 35 [76]; NF-1886, 7 [6]; GM-I-11). Showing justice to 'lower people' meant treating them with intolerance (JGB262). Such distinctions apply across the board: people have duties only to their equals (JGB-260). What is permitted for 
one type is not permitted for others (JGB-260; NF-1887, 11 [127]; NF-1987, 11 [146]). 'Higher people' should live beyond good and evil; for 'lower types' some form of morality remains necessary (NF-1883, 9 [47]; AC-54).

Nietzsche regarded himself as an exception among the exceptional, but what does it mean to be exceptional if there is no individual? Nietzsche sometimes suggested that only a few people are (or become) persons (NF-1887, 10 [59]), others being 'ein Rendezvous von Personen' (NF-1888, 16 [89]). Persons are primarily synthesising beings, not analytical ones (NF-1887, 9 [119], NF-1887, 10 [17], NF-1887, 10 [111]), able to bring together all the aspects in themselves and to make sense of (not find sense in) the world of flux. They are creators rather than knowers, who say, 'This should be' rather than 'This is' (JGB-211: cf. MA-I-94; JGB-9). Progress depends on them alone (JGB-257), although, being great destroyers too, their effect is unpredictable (FW-370 and elsewhere). Nietzsche's heroes, Julius Caesar and Napoleon, were creators and destroyers on a grand scale who said 'yes' to the will to power and therefore to life itself.

The apogee of creativity, it seems, is giving orders. Probably Nietzsche was influenced by Genesis in which creation arises from the divine fiat (cf. GM-I-2). To give orders is to create an order, a Rangordnung; to evaluate is to create (Za-I-Ziel). Those who give orders are distinguished because they make distinctions (cf. FW-301; JGB-225). Since commanding and obeying are reciprocals, Nietzsche held that some form of slavery must be the lot of those fit only to serve (JGB-207; JGB-258). Typically, he argues that it would be practical to grant workers many benefits, provided that they have no significant power (MA-I-93; WS-286; NF-1883, 9 [47]). Still others have no right to live (NF-1884, 25 [343]) and should be 'helped to go under' (AC-2; cf. JGB-62; GM-I-12).

Those who say 'no' to the will to power do not escape its workings. Lacking the overt power of 'higher people', they exert power in sneaky ways ('Schleichwege' - GM-II-14), using morality, particularly the morality of equality, human rights and compassion, as a tool. Morality arises when the slaves revolt against the masters and reverse the 'natural' order based on power (JGB-195; GM-I-7; NF-1888, 15 [44]). It is born of ressentiment, the 'vengeful thinking' (Sinhababu 2007:264) or 'frustrated vindictiveness' (Solomon 1994:95) of the slaves. There is some sense in this. In Christian morality, the burdens mostly fall on the 'strong' (who must give handouts, show compassion, awards rights, etc.), while the weak, having nothing to contribute, reap the benefits. Even after that, the weak are, by default, the morally good and holy (JGB-195; GM-I-13), while the strong are at best suspect (AC-51).

Nietzsche, who had 'nothing but contempt for most forms of human life' (Leiter 2020:1.3) despised this above all (cf. GM, EH, AC passim). Ressentiment, he believed, weakens and debases the strong (JGB-228; EH-Bücher-5), while the weak gain little, because their weakness is not a result of political contingency but belongs to their essence (Wesen) (GM-I-13; cf. Schacht 2013:335). They succeed only in poisoning the wells (Bittner 1994:134ff.). Mitleid, for instance, means that the healthy suffer with the sickly, thereby increasing suffering (M-134; AC-7). Ressentiment closely resembles the vice of envy (invidia) - Nietzsche did sometimes use Neid as an equivalent. Whereas greed says, 'If you have it, I must have it too', envy says, 'If I cannot have it, you may not have it either' (cf. Fairlie 1978:64f). 'My heart conceived more joy from others' loss than my own gain', says one of the envious in Dante's Purgatory (Canto XIII, 110f.), while another says he was livid if he saw someone 'looking pleased with life' (Canto XIV, 83f.). Predictably, Nietzsche's slaves 'try to poison the happiness of the fortunate' (Anderson 2017:2; cf. GM-III-14).

This lies at the heart of Nietzsche's attack on Christianity. He did not object (much) to God as cosmic tyrant (cf. GM-I-23; AC-22) but to the God of lowly (GD-Verbesserer-3; AC-43), the God on the cross (JGB-46; GM-I-8; AC-51) and the notion of equality before God (JGB-219; NF-1887, 11 [153]; AC-62). This makes Christianity worse than other religions, although he rejected them all. Moreover, communism, socialism and democracy are merely secular equivalents of Christianity: socialism is latent Christianity (NF-1887, 10 [2]) and Christianity is in origin simply a socialist doctrine (NF-1887, 11 [379]). The religious or secular doctrine of love and equality, like the bite of a spider, poisons the world (Za-II-Taranteln).

Focusing on enticing and thought-provoking parts in Nietzsche will not make other parts go away. His silly remarks such as the one about female cooks (JGB-193) show that Nietzsche is not always profound when he is puzzling. Nietzsche scholars would do well to pay more attention to these 'margins' in his writings and to the views of contemporaries, who are often unfairly denigrated. Yet even if, as Millgram (2012:26f.) surmises, Nietzsche could never resolve the tensions within himself, the questions he posed remain. In a world of flux, can we have identities that are more than useful lies - useful for gaining power? Can even useful lies apply to us if we are conglomerates and never identical to ourselves? Or can we have identities only if we are, by choice or chance, utterly stereotypical - and utterly boring?

\section{Challenges}

We cannot dismiss Nietzsche's views as the rantings of a megalomaniac. As indicated here, some of what he said makes sense. At several points he issued challenges that we cannot conveniently evade. Some of them are discussed here.

As long as we, consciously or unconsciously, see identity purely in terms of power and power struggles, Nietzsche will haunt us. If identity remains caught in a circuit of domination and resistance, Nietzsche's dictum that life is the will to power (JGB-13; JGB-36; NF- 2 [190]) sounds plausible. Terms that, although sounding better, remain within the ambit of power and power struggles (politics, empowering, struggle, confronting, subverting, challenging, etc.) hardly help. 
[What exactly Nietzsche meant by the will to power remains unclear: scholars give an array of incompatible accounts - see Leiter (2020:3.1) for some. Perhaps it remained 'an empty, metaphysical concept' (Geuss 1997:13). What is clearer is that he used it to disqualify most other motives.]

Discourses of power perpetuate power relationships - with reassigned roles - if power remains the bottom line. Nietzsche showed how easily goals such as liberation, love and justice can be reduced to the search for power (NF-1887, 9 [145]). And power, he clearly saw, is inherently non-moral and hierarchical. As Anderson (2017:2) points out, 'excellence' implies inequality. While envisaging a sublimated form of power struggle (FW-283), Nietzsche did not exclude tyranny (Anderson 2017:3.1; cf. Foot 1994:6ff.; Nehamas 1999) or coercion (JGB-188; GD-Verbesserer-3). The words Kampf and Krieg (and their derivatives) clutter Nietzsche's pages. 'Der freie Mensch ist Krieger' (GD-Streifzuege-38); 'Alles Geschehen ist ein Kampf' (NF-1885, 1 [92]). Ultimately, power is manifest only in effective overpowering (M-113; JGB-259; GM-II-12). Do 'subversive discourses' really get the better of nuclear arsenals? If so, how and to what end?

The escape into the glorious freedom of 'different perspectives' and 'multiple interpretations' is illusory. Firstly, both Leiter (1994) and Gemes (2013) have argued compellingly against the 'received view' that Nietzsche's perspectivism entails epistemological relativism. For instance, he never held that all perspectives and interpretations are equal (Leiter 1994:340f; cf. BGE-22; GM-III-13). Secondly, rejoicing in cultural differences, diverse gender identities and creative interpretations (etc.) leaves those decisions that affect people's lives and have to be made untouched. Justice (for instance) has to be served now and inexorably imposes an 'either-or'. Even in academia the prevailing view is the one that has prevailed over others, while those with countervailing views risk being 'de-platformed'.

Are there sources of identity that are not power disguised or power deferred? Of old many regarded truth as such a source. Nietzsche's complex and changing thoughts on truth cannot be discussed here - see Clark (1990:1-127) for a full, widely accepted account. Some of his epigones, however, have been blunt; truth has been annexed to power as power-knowledge. Our feelings of human solidarity (compassion, etc.), beauty, wonder and awe, joy, longing and justice too were candidates as long as they were regarded as inherent to human nature. Now that they are proclaimed to be (social) constructs, they are under fire. All mere social constructs can be interpreted as reflexes of the will to power.

Perhaps there is an independent 'will to powerlessness' that cannot be reduced to masochism or self-sacrifice and that relates both to our joyful terms 'captivated', 'fascinated', 'entranced' and 'swept off our feet' (as Nietzsche initially was by Wagner's music) and to our longing to depend and be depended on, as explained by Gilligan (1993:21f. and passim). It would not be less 'Dionysian' than the will to power and
Nietzsche did once consider it (M-271), seeing it as necessary preparation for new power struggles. Discourses on identity will be richer and more hopeful, if this term and others mentioned here can maintain themselves alongside power. Not in place of power, because that would be both impossible and undesirable. Kenneth Burke (1952:124) speaks of 'Love, Knowledge, Authority' as ideally a trinity.

A richer vocabulary is also needed to counter Nietzsche's claim that morality arises from ressentiment. Much of what he says rings chillingly true (cf. Anderson 2017:2). Have you never heard the dulcet voice of justice but felt the grasping hands of greed? Have you never seen eyes eager to drag others down to their level? It is easier to foist your humiliation, deprivation and abjection on others than to strive to attain their abilities, voice and agency. 'Im Grunde sind wir allesamt eigennüztiges Vieh und Pöbel' (NF-1884, 26 [282]), or 'equal worthlessness in the eyelessness of Godlessness' (Burke 1952:334). It is easier too for the privileged to salve their consciences by imposing hardships on their peers than to help the non-privileged to equality by treating them as equals, that is, not lowering standards or withholding criticism. We are not that indulgent to those we really regard as equals.

When there is a disjunction between the easy equality we automatically accord to some and the strained 'equality' we award to others, ressentiment will flourish (cf. GM-III-14). The 'compassion' (understanding) shown to the second group is degrading and perpetuates weakness and resentment. Then 'identities' arise in which groups define themselves primarily in counter-distinction to other groups, leading to a 'plurality in hostility'. Further 'identity markers', often taken from a fictional past, accrue later. The entire process is reactive and oppositional (cf. GM-I-10) rather than creative. Would you rather be criticised or be patronised? Would you rather be told that you are wrong or that allowances are made for you because you cannot possibly understand?

Here we may need a vocabulary that goes beyond power and justice. Love, the obvious candidate, is too protean a term to be of practical use. Nietzsche enjoyed showing how love can be part of a power game (M-532, FW-14, Za-II-Ueberwindung; GM-I-8). Generosity, the traditional counterpart of envy, does not escape Nietzsche either. Der schenkende Tugend (Za-I-Tugend-1), apparently generosity, is possible only to those who have selfishly acquired much power in various forms and then give as a display of their superabundance. Think of Andrew Carnegie. Gustavo Gutiérrez's term 'gratuitousness' may be best, particularly because Gutiérrez insists that gratuitous love lies beyond justice (Gutiérrez 1984:110, 1987:112ff.). Nietzsche himself saw mercy, a prerogative of the strongest, as something beyond justice (GM-II-10) and praised Christianity, Hinduism and Buddhism for not making redemption dependent of 'works' (GM-III-17). Possibly Nietzsche's 'beyond good and evil' can be countered by 'beyond justice and injustice'. Beyond, not in place of. 
Without intercourse with other 'identities', any 'identity' falls victim to inbreeding and eventual degeneracy. Although Nietzsche would have approved of the biological metaphor, his insistence that some cannot and may not understand him sounds ominous. Are meaningful interchanges possible only inter pares, among those who share an identity? The pathos of identity is the pathos of maximal distance? Anything else risks domination? Such notes are too often sounded in identity discourses. It seems better to say, adapting Nietzsche (Za-II-Taranteln), 'Identities are not pure!'

Our 'shared humanity', formerly seen as a bridge linking various identities, now evokes disputes about what exactly is shared, followed by accusations of essentialism. Much acrimony can be avoided if we note that disputes and accusations are instances of communication. Identity is expressed, verbally or otherwise, and communicated to others. If communication precedes identity as existence precedes essence, we need a transcendental critique of communication (along the lines of Habermas and Benhabib) before seeking a coherent theory of identity - unless we adopt a crass form of biologism.

What Nietzsche says about persons challenges us to rethink the question of individuality (not individualism) and agency. The individualist-communalist binary is sterile. In expounding African communitarian (not communalist) ethics, Gyekye (2011:3, 4) starts with character and personhood. Humans are born; personhood is attained and turns on moral accountability. It is acquired in the community but enables the person to function independently. Without this independence, the person cannot effectively contribute to the community. This makes perfect sense.

Nicholson (2010:46f) points out that historically individuality has mostly been the privilege of those with power. For instance, women (blacks, etc.) had an identity as a group: their characteristics were attributed to the group. Men, being 'the norm', were not lumped together: they had personalities, not a shared identity. Perhaps we attribute identities to groups because we deny their members personalities. They are treated as herds, while independence is 'ein Vorrecht der Starken' (JGB-178). Afterwards people may embrace the attributed group identity because that alone allows them to be heard.

Here Nietzsche's insistence on the value of solitude (e.g. JGB-212) cannot be ignored. It is an ethical matter, for etymologically at least 'having a conscience' means 'knowing with yourself', not simply with others. If you cannot be alone, how can you ever stand alone? Dorfman's (2004) play Manifesto for another world gives voices to a series of people from across the world who stood up for good causes. Some paid with their lives - one just after the play was first performed (Dorfman 2004:21n). The first voice says: 'Courage begins with one voice. It's that simple. I did what I had to do. Anything else would have tasted like ashes' (Dorfman 2004:27). These words, in various selections and combinations, recur throughout the play. Or should we wait for the chorus and then join it?

Nietzsche was a moralist who, in his battle against the dominant morality, called himself an immoralist (see Geuss (1997, a particularly clear discussion), Clark (1994:16ff.; 2015:4), Leiter (2020:1.1), pace Sinhababu (2007), Berry (2015: 378ff.). His ethos is too harsh for me and his gospel is bad news for most people. Although his negations were many, sharp and witty and his affirmations few and faltering, he sought something to affirm (FW-276). To say 'no' effectively, one has to say 'yes'. For instance, it is not clear what 'the nation state is violent' implies unless one can point to a social ordering that is not (or significantly less) violent. Criticism by itself, without appreciation, does not make anything appreciate in value; instead, everything sinks into decadence by itself. This seems to be Nietzsche's (valid) point.

It is riskier to affirm than to criticise. In the section Was ist vornehm in Jenseits von Gut und Böse, Nietzsche seems to affirm the consummate prig. To move beyond Nietzsche's reductive hierarchy requires more than the facile deconstruction of hierarchies. A pluralism that retains equality and rights as safety nets but abandons them as ultimate goals may undercut Nietzsche, lead to a more joyful science and liberate us from the burdens of fraught identities. What exactly is identity? Perhaps we should say, in Nietzsche's words, not in his spirit, that it is what we want it to be - that which we can wholeheartedly affirm.

Perhaps. 'Please understand, I never said I had a secret chart to get me to the heart of this or any other matter' (Leonard Cohen, Stranger Song).

\section{Notes}

Nietzsche is quoted from the Digitale Kritische Gesamtausgabe Werke und Briefe (eKGWB), a digital version of the standard Kritische Gesamtausgabe edited by Colli and Montinari. The digital edition, available at www.nietzschesource.org/ eKGWB, is open-access, stable and searchable. References use the standardised acronyms established by Colli and Montinari and the forms followed in $e K G W B$. The standardised (German) acronyms are as follows:

AC: Der Antichrist (completed 1888, first published 1908).

EH: Ecce Homo (1888).

FW: Die fröliche Wissenschaft (1881-2; Preface and Book 5 1886).

GD: Götzen-Dämmerung (1888).

GM: Zur Genealogie der Moral (1887).

JGB: Jenseits von Gut und Böse (1886).

MA I: Menschliches, Allzumenschliches I (1878; New preface 1886).

M: Morgenröthe (1881; Preface 1886).

VM: Vermischte Meinungen und Sprüche = Menschliches, Allzumenschliches II part 1 (1879; Preface to this and the next 1886).

WS: Der Wanderer und sein Schatten = Menschliches, Allzumenschliches Menschliches II part 2, (1880).

Za: Also Sprach Zarathustra (Books I \& II 1883, Book III 1884, Book IV 1885). 
References are given as follows (as in eKGWB):

Notebooks: NF-year of first entry in the notebook, number assigned to the notebook and number (in square brackets) assigned to the entry (NF-1886, 2 [12]).

Letters: BVN-year of the letter, number assigned to the letter (BVN-1884, 353).

$\mathrm{EH}$ and GD: Acronym-abbreviated section title-subsection number (GD-Moral-6).

Za: Acronym-book number (roman)-abbreviated section titlenumber of subsection when applicable (Za-III-Tafeln-24).

GM: Acronym-essay number (roman)-subsection number (GM-I-10).

All works with consecutively numbered sections: Acronymsection number (JGB-25 or for MA I, acronym-I-54)

Prefaces: Acronym-Vorrede-subsection when applicable.

\section{Acknowledgements Competing interests}

The author declares that he has no financial or personal relationships that may have inappropriately influenced him in writing this article.

\section{Author's contributions}

D.G.L. is the sole author of this research article.

\section{Ethical considerations}

This article followed all ethical standards for research without direct contact with human or animal subjects.

\section{Funding information}

This research received no specific grant from any funding agency in the public, commercial or not-for-profit sectors.

\section{Data availability}

Data sharing is not applicable to this article as no new data were created or analysed in this study.

\section{Disclaimer}

The views and opinions expressed in this article are those of the author and do not necessarily reflect the official policy or position of any affiliated agency of the author.

\section{References}

Anderson, R.L., 2017, 'Frederick Nietzsche', in The Stanford Encyclopedia of Philosophy, Summer 2017, viewed 13 February 2021, from https://plato.stanford edu. archives/summer2017/entries/nietzsche/.

Andreas-Salomé, L., n.d. (1894), Nietzsche in seiner Werke, Carl Reissner, Dresden.

Berry, J., 2015, 'Is Nietzsche a virtue theorist?', Journal of Value Inquiry 49, 369-386. https://doi.org/10.1007/s10790-015-9494-9.
Bittner, R., 1994, 'Ressentiment', in R. Schacht (ed.), Nietzsche, genealogy, morality: Essays on Nietzsche's on the genealogy of morals, pp. 127-136, University of California Press, Berkeley, CA.

Bittner, R., 2003, 'Introduction', in R. Bittner (ed.), Friederxich Nietzsche: Writings from the late notebooks, transl. K. Starge, pp. ix-xxxiv, Cambridge University Press, Cambridge.

Burke, K., 1952, A grammar of motives, Prentice Hall, New York, NY.

Cate, C., 2003, Friedrich Nietzsche: A biography, Pimlico, London.

Clark, M., 1990, Nietzsche on truth and philosophy, Cambridge University Press, Cambridge.

Clark, M., 1994, 'Nietzsche's immoralism and the concept of morality', in R. Schacht (ed.), Nietzsche, genealogy, morality: Essays on Nietzsche's on the genealogy of morals, pp. 14-34, University of California Press, Berkeley, CA.

Clark, M., 2015, On the genealogy of morals, OUP, Oxford.

Cohen, L., 1967, Stranger song, (C) Columbia Records.

Dante (Dante Alighieri), 1955, Purgatory, transl. D.L Sayers, Penguin, Harmondsworth. De Man, P., 1979, Allegories of reading, Yale University Press, New Haven, CT.

Dorfman, A., 2004, Manifesto for another world: Voices from beyond the dark, Seven Stories, New York, NY.

Fairlie, H., 1978, The seven deadly sins today, University of Notre Dame Press, Notre Dame.

Fish, S., 2016, 'Don't blame Nietzsche for Donald Trump', Foreign Policy, 09 August, 2016, viewed 22 February 2021, from www.foreignpolicy.com/2016/08/09/don'tblame-nietzsche-for-donald-trump/.

Foot, P., 1994, 'Nietzsche's immoralism', in R. Schacht (ed.), Nietzsche, genealogy morality: Essays on Nietzsche's on the genealogy of morals, pp. 1-13, University of California Press, Berkeley, CA.

Gemes, K., 2013, 'Life's perspective', in K. Gemes \& J. Richardson (eds.), The Oxford handbook of Nietzsche, pp. 553-575, OUP, Oxford.

Geuss, R., 1997, 'Nietzsche and morality', European Journal of Philosophy 5(1), 1-20. https://doi.org/10.1111/1468-0378.00024

Gilligan, C., 1993, In a different voice: Psychological theory and women's development, 2nd edn., Harvard University Press, Cambridge, MA.

Gilman, S. (ed.), 1987, Conversations with Nietzsche: A life in the words of his contemporaries, transl. D.J. Parent, OUP, New York, NY.

Gutiérrez, G., 1984, We drink from our own wells, transl. M.J. O'Connell, Orbis, Maryknoll, New York, NY.

Gutiérrez, G., 1987, On job, transl. M.J. O'Connell, Orbis, Maryknoll, New York, NY.

Gyekye, K., 2011, 'African ethics', in The Stanford Encyclopedia of Philosophy, Fall 2011, viewed 13 February 2021, from https://plato.stanford.edu.archives/ fall2011/entries/african-ethics/.

Leiter, B., 1994, 'Perspectivism in Nietzsche's genealogy of morals', in R. Schacht (ed.), Nietzsche, genealogy, morality: Essays on Nietzsche's on the genealogy of morals, pp. 334-352, University of California Press, Berkeley, CA.

Leiter, B., 2019, Moral philosophy with Nietzsche, OUP, Oxford.

Leiter, B., 2020, 'Nietzsche's moral and political philosophy', in The Stanford Encyclopedia of Philosophy, Spring 2020, viewed 13 February 2021, from https:// plato.stanford.edu.archives/spring2020/entries/nietzsche-moral-political/.

Millgram, E., 2012, 'Who wrote Nietzsche's autobiography?', Draft, viewed 19 February 2021, from www.elijahmillgram.net.

Nehamas, A., 1999, 'Nietzsche and “Hitler"', Southern Journal of Philosophy 37 (Suppl. 1), 1-15. https://doi.org/10.1111/j.2041-6962.1999.tb01790.x

Nicholson, L., 2010, 'Identity after identity politics', Washington University Journal of Law \& Policy 33, 43-74.

Porter, J.I., sd., Nietzsche, rhetoric, philology (Final), viewed 02 March 2001, from www.academia.edu/15120050/Nietzsche_Rhetoric_Philology_Final_.

Schacht, R., 2013, 'Nietzsche's genealogy', In K. Gemes \& J. Richardson (eds.), The Oxford handbook of Nietzsche, pp. 323-343, OUP, Oxford.

Schmidt, J., 2016, Der Mythos 'Wille zur Macht', De Gruyter, Berlin.

Sinhababu, N., 2007, 'Vengeful thinking and moral epistemology', in B. Leiter \& N. Sinhababu (eds.), Nietzsche and morality, pp. 262-280, Clarendon, Oxford.

Solomon, R., 1994, 'One hundred years of ressentiment: Nietzsche's genealogy of morals', in R. Schacht (ed.), Nietzsche, genealogy, morality: Essays on Nietzsche's on the genealogy of morals, pp. 95-124, University of California Press, Berkeley, CA.

Van Tongeren, P., 2015, 'Esprit Libre et Démocratie', Studia Nietzscheana, viewed 02 March 2020, from www.nietzschesource.org/SN/2015/. 